\title{
MINERAL ADSORBENTS IN BROILERS NUTRITION - EFFECTS ON YIELD AND MEAT QUALITY
}

\author{
Đorđe G. Okanovićc ${ }^{\star}$, Dejan R. Karović ${ }^{2}$, Slobodan Lilić ${ }^{3}$, Vera A. Radović ${ }^{2}$, Slavko S. Filipović ${ }^{1}$. \\ ${ }^{1}$ University of Novi Sad, Institute of Food Technology, Bulevar cara Lazara 1, 21000 Novi Sad, Serbia \\ ${ }^{2}$ University of Kragujevac, Faculty of Agronomy, Cara Dušana 34, 32000 Čačak, Serbia \\ ${ }^{3}$ Institute of Meat Hygiene and Technology, Kaćanskog 13, 11000 Belgrade, Serbia
}

\author{
*Corresponding author: \\ Phone: +381214853707 \\ Fax: +38121450725 \\ E-mail address: djordje.okanovic@ fins.uns.ac.rs
}

\begin{abstract}
In this paper are presented the results of investigation of the application of mineral adsorbents in broiler diet. Total of 400 broilers Cobb 500 provenience were divided into 4 groups: control group (C) of broilers fed without added mineral adsorbent; $1^{\text {st }}$ group with added Min-a-zel in the amount of $0.5 \% ; 2^{\text {nd }}$ group with added Min-a-zel Plus in the amount of $0.2 \%$; and $3^{\text {rd }}$ group with added Min-a-zel Plus in the amount of $0.3 \%$. Fattening lasted for 42 days. Broilers were reared on the floor stocking system; feed and water supply were ad libitum. Fattening performances such as live body weight, feed consumption, feed conversion ratio and production number were better in group of broilers that was fed a diet with added mineral adsorbents. Broilers from the $1^{\text {st }}$ group achieved the highest live weight and had the lowest feed consumption and feed conversion ratio, and also the best production number. Slaughter characteristics of broilers in the $1^{\text {st }}$ group were also the best. They had the biggest share of the most valuable parts, breast and drumsticks. Obtained results showed that mineral adsorbents can be successfully used as additives in the diets for broilers for improved production and better fattening performances.
\end{abstract}

Key words: broilers, fattening, mineral adsorbents, performances

\section{INTRODUCTION}

Solution for larger production of food for humans and feed for animals is using of new technologies in biotechnology. Basic orientation are new technological procedures that have aim to improve nutritive value of food and feed, as well as valorization of by-products of food production and primary agricultural production (Tica et al., 2009; 2010).

Performances of broilers in fattening, their slaughter characteristics and meat quality are linked to pre-mortal and post-mortal factors (Ristić et al., 2005). It is considered that diet, as a pre-mortal factor, dominantly impacts with more than $30 \%$ the quality of carcasses and meat (Barbut et al., 2005; Andersen et al., 2005; Blagojević et al., 2009).

Main aim in broiler fattening is to obtain the highest live weight in the shortest period of time with high proportion of muscles (especially the most valuable: breast and leg), minimum proportion of bones in the carcass, as well as good productive performances such as low feed conversion ratio. These results depend on breed, sex and nutrition. When studying the growing chickens, it is often necessary to determine the whole body composition (Andrássy-Baka et al., 2003) and body mass index (Mendes et al., 2007). Also, the quality of the carcass can be assessed on the 
basis of a number of criteria for evaluation of sensory, morphological, histological, physical, chemical, health, hygienic and technological properties and features (Straková et al., 2006). Many investigations contributed to breed, sex and diet impact on the carcass composition and tissue weight distribution of broiler chickens (Bašić et al., 2009; Cmiljanić et al., 2005; Shahin and Elazeem, 2005).

Presence of mycotoxins in feed mixtures is worldwide problem. Their alimentary ingestion can cause intoxication of many animals in one herd (Elaroussi et al., 2008; Stevanović et al., 2011). Besides this, residues of mycotoxins in animal products could cause intoxication in humans (Lilić et al., 2010; Karović et al., 2013).

Zeolite minerals in inorganic form absorb polar mycotoxins as aflatoxin and ergot alkaloids, but do not absorb vitamins, microelements and amino acids. Becides the absorption of mycotoxins, zeolite absorbs bacterial toxins and gases. It is nonresorbtive and do not leave residues in meat and eggs. Due to these properties, it improves feed conversion ratio and performances in the fattening (Miazzo et al., 2005).

Dobeic et al. (1994) (cited by BočarovStančić et al., 2001) reported better weight gain of broilers (1.7-2.6\%) fed the feed mixtures with added zeolites as well as better feed consumption (5.9-6.4\%) than the broilers fed the feed mixtures without zeolites. Zeolite (clinoptilolite) in amount of $1.2 \%$ and $4 \%$ had positive influence on weight gain and live weight of broilers. Feed conversion ratio was better when $2 \%$ of zeolite has been added.

Adding of "Min-a-zel“ in amount of $0.5 \%$ in feed mixtures had positive influence on live weight and weight gain of broilers and made impossible the deposing of aflatoxin B1 in organs (Resanović et al., 2009).

Boyer (2000) (cited by Karović et al., 2013) stated that clinoptilolite presence in animal fodder would lead to a significant increase of feed efficiency as well as reduction of potential for intestinal diseases (diarrhoea), whereby the toxic effect of ammonium ions surplus would be redu- ced. Some researchers explain this with the existence of the clinoptilolite preference for large ions such as $\mathrm{NH}_{4}{ }^{+}$, so it serves as a reservoir for ammonia. Also, using of zeolites in diets has positive impact on lowering of mortality, good health and better quality of eggs and meat (Bogosavljević-Bošković et al., 2009; Okanović et al., 2013).

The aim of this study was to investigate the impact of adding mineral adsorbents natural zeolite under the commercial names "Min-a-zel" and "Min-a-zel-Plus" in the feed mixtures, on fattening performances and slaughter characteristics of broilers.

\section{MATERIAL AND METHODS}

In this study, a total of 400 broilers Cobb 500 provenience were used. Broilers were divided into four groups: control (C), $1^{\text {st }}$ experimental, $2^{\text {nd }}$ experimental and $3^{\text {rd }}$ experimental group. For each group were used feed mixtures that meet normative (Serbian Regulations, 2010) for this provenience - starter (1-14 ${ }^{\text {th }}$ day), grower (15$34^{\text {th }}$ day) and finisher (35-42 $2^{\text {nd }}$ day). Raw materials and proximate composition of feed mixtures are presented in Table 1.

Proximate composition (moisture content, crude protein content, crude fibre, crude fat content and ash content) of complete feed mixtures used for broiler diets was determinated according to AOAC methods (1995).

Broilers in the control group were fed diet without added zeolite, while broilers in experimental groups were fed diets with added zeolite: $1^{\text {st }}$ group contained $0.5 \%$ of "Min-a-Zel", $2^{\text {nd }}$ group contained $0.2 \%$ of "Min-a-Zel Plus" and $3^{\text {rd }}$ group contained $0.3 \%$ of „Min-a-Zel Plus“.

All the diets were provided ad libitum and conventional breeding and rearing practices were followed.

"Min-a-Zel" is the product obtained from natural zeolite (clinoptilites) with good balance of calcium, sodium and potassium. "Min-a-Zel Plus" is obtained by modification of zeolites using organic cations (Adamović et al., 2003). The structure of natural zeolites is such that they are good adsorbents of small organic molecules. 
Table 1.

Raw materials and proximate composition of feed mixtures

\begin{tabular}{lrrr}
\hline & Starter & Grower & Finisher \\
\hline Corn, \% & 47.00 & 52.00 & 50.00 \\
Corn gluten, \% & 3.00 & - & - \\
Soyabean meal, \% & 22.00 & 17.50 & 15.00 \\
Soyabean grits, \% & 15.00 & 10.00 & 10.50 \\
Wheat, \% & 5.00 & 10.00 & 15.00 \\
Soyabean oil, \% & 2.50 & 4.00 & 4.00 \\
Yeast, \% & - & 1.00 & 1.00 \\
Limestone, \% & 1.00 & 1.00 & 1.00 \\
Dicalciumphosphate, \% & 2.20 & 2.20 & 2.20 \\
Premix, \% & 1.00 & 1.00 & 1.00 \\
Salt, \% & 0.30 & 0.30 & 0.30 \\
Lysine, \% & 1.00 & 1.00 & - \\
& & & \\
Crude protein, \% & 21.66 & 18.28 & 16.54 \\
Crude fat, \% & 7.90 & 6.73 & 5.52 \\
Moisture, \% & 9.83 & 10.50 & 10.65 \\
Crude fibre, \% & 4.90 & 5.36 & 5.79 \\
Ash, \% & 6.40 & 6.69 & 7.83 \\
\hline
\end{tabular}

The modification of zeolite was done with the cation exchange on the surface - inorganic cations were replaced with organic cations.

This changes the surface electricity and hydrophobic properties. Adsorption efficiency of this modified mineral adsorbent „Min-a-zel Plus" is more than $90 \%$ for aflatoxins, zearalenon, ochratoxin $A$ and group of ergot alkaloids (Tomašević-Čanović et al., 2003).

Both „Min-a-Zel“ and "Min-a-Zel Plus“ were manufactured by the Institute for technology of nuclear and other mineral raw materials, Belgrade, Serbia.

Fattening performance was measured by the following parameters: live weight, feed consumption and feed conversion ratio, as well as production index using the formula (Radović et al., 2003):

Production index $=\{$ Live weight $(\mathrm{kg}) \mathrm{x}$

(100-percentage of mortality) $\times 100\}$ /

\{Fattening period (days) $\mathrm{x}$

Feed conversion ratio $(\mathrm{kg})\}$

From each group, 4 males and 4 females were weighed and slaughtered. After slaughtering, cold carcasses were weighed and dissected. For each carcass, the carcass yield was calculated as a percen- tage of cold carcass from live weight and also the masses of breast, legs, back, neck, wings and abdominal fat were determined.

Analysis of variance (ANOVA) was applied to compare means at $1 \%$ and $5 \%$ significance level using the statistical data analysis software system STATISTICA (2008).

\section{RESULTS AND DISCUSSION}

Results of mortality and fattening performances of broilers are presented in Table 2.

The highest mortality of $7 \%$ was in the control group (C), $3 \%$ was in the $1^{\text {st }}$ and $2^{\text {nd }}$ group and the least $2 \%$ in the $3^{\text {rd }}$ group.

The highest feed consumption (3677 g) had broilers from the control group. In other groups, broilers had similar feed consumption, in the $1^{\text {st }}$ group $3660 \mathrm{~g}$, in the $2^{\text {nd }} 3670 \mathrm{~g}$ and in the $3^{\text {rd }}$ group $3665 \mathrm{~g}$ per broiler.

Average live weight of broilers at the end of the fattening period was significantly different $(P \leq 0.01)$. The highest average live weight of $2136 \mathrm{~g}$ had broilers fed diet with added „Min-a-zel“ $0.5 \%$ ( $1^{\text {st }}$ group). Lower average live weight was recorded in 
the $3^{\text {rd }}$ group of broilers $(1941 \mathrm{~g})$, the $2^{\text {nd }}$ group (1853 g) and C group (1697 g).

One of the main parameters that show quality of broiler production is the production index, which is linked to live weight, feed consumption and feed conversion ratio. According to obtained results, production index was the highest in the $1^{\text {st }}$ group (287.1), lower in the $3^{\text {rd }}$ (239.1) and $2^{\text {nd }}$ group (216.6) and the least in C group (174.4).

It can be concluded that broilers from the $1^{\text {st }}$ and $3^{\text {rd }}$ group, that had Min-a-zel $0.5 \%$ and Min-a-zel Plus $0.3 \%$ in diets had better results than broilers that had no zeolite in diet and that had Min-a-zel Plus in the amount of $0.2 \%$ in the diet.

In the accordance with literature data about fattening performances of broilers, ascertainment is that broilers from $1^{\text {st }}$ group achieved very good results for this provenience (Blagojević et al., 2009). It should be noted that broilers fed a diet with added modified clinoptilites had better performances than broilers from control group (Nešić et al., 2004) and according to that statistically significant differences $(P \leq$ 0.01 ) between average values were observed.

Results on carcass weight and slaughtering characteristics are shown in Tables 3, 4 and 5.

From Table 3, it can been seen that broilers of the control group $(C)$ had the least carcass weight $(1220 \mathrm{~g})$. The highest average carcass weight had broilers from the $1^{\text {st }}$ group $(1540 \mathrm{~g})$, while lower values had broilers from the $3^{\text {rd }}(1402 \mathrm{~g})$ and the $2^{\text {nd }}$ group $(1333 \mathrm{~g})$. Those average values were significantly different $(P \leq 0.01)$. It can be concluded that carcass weight was in very strong correlation with final live weight of broilers, which is in line with data of Tokić et al. (2007) and Radović et al. (2009). Adding of zeolite in feed mixtures had positive impact on final live weight of broilers.

Table 2.

Mortality and fattening performances

\begin{tabular}{|c|c|c|c|c|c|}
\hline Group & Mortality, \% & $\begin{array}{c}\text { Feed } \\
\text { consumption } \\
\text { g/broiler }\end{array}$ & $\begin{array}{l}\text { Live weight } \\
\text { g/broiler }\end{array}$ & $\begin{array}{c}\text { Feed } \\
\text { conversion } \\
\text { ratio, } \mathrm{kg} / \mathrm{kg}\end{array}$ & $\begin{array}{l}\text { Production } \\
\text { index }\end{array}$ \\
\hline C & 7 & 3677 & $1697^{x}$ & 2.16 & 174.4 \\
\hline Index & 100.00 & 100.00 & 100.00 & 100.00 & 100.00 \\
\hline $1^{\text {st }}$ & 3 & 3660 & $2136^{y}$ & 1.71 & 287.1 \\
\hline Index & 42.86 & 99.54 & 125.85 & 79.41 & 164.63 \\
\hline $2^{\text {nd }}$ & 3 & 3670 & $1853^{q}$ & 1.97 & 216.6 \\
\hline Index & 42.86 & 99.81 & 109.20 & 91.53 & 124.22 \\
\hline $3^{\text {rd }}$ & 2 & 3665 & $1941^{z}$ & 1.89 & 239.1 \\
\hline Index & 28.57 & 99.67 & 114.37 & 87.51 & 137.09 \\
\hline
\end{tabular}

Table 3.

Live weight of broilers, carcass wight and carcass yield $(n=32)$

\begin{tabular}{ccccc}
\hline Group & & Live weight, g & Carcass weight, g & Carcass yield, \% \\
\hline C & Mean & $1697^{\mathrm{x}}$ & $1220^{\mathrm{x}}$ & 71.87 \\
& SD & 80.7 & 61.3 & 0.7 \\
& Index & 100.0 & 100.0 & 100.0 \\
$1^{\text {st }}$ & Mean & $2136^{\mathrm{y}}$ & $1540^{\mathrm{y}}$ & 72.10 \\
& SD & 68.1 & 49.0 & 0.6 \\
& Index & 125.8 & 126.2 & 100.3 \\
$2^{\text {nd }}$ & Mean & $1853^{\mathrm{q}}$ & $1333^{\mathrm{q}}$ & 71.93 \\
& SD & 27.5 & 39.6 & 1.3 \\
& Index & 109.2 & 109.3 & 100.1 \\
$3^{\text {rd }}$ & Mean & $1941^{z}$ & $1402^{z}$ & 72.20 \\
& SD & 50.6 & 53.1 & 1.0 \\
& Index & 114.4 & 114.9 & 100.5 \\
\hline
\end{tabular}

Means within the same column with different superscript letters are different $(P \leq 0.01)$ 
Table 4.

Yield and share of breast, drumstick and back $(n=32)$

\begin{tabular}{|c|c|c|c|c|c|c|c|}
\hline \multirow{2}{*}{ Group } & & \multicolumn{2}{|c|}{ Breast } & \multicolumn{2}{|c|}{ Drumstick } & \multicolumn{2}{|c|}{ Back } \\
\hline & & g & $\%$ & g & $\%$ & g & $\%$ \\
\hline \multirow[t]{3}{*}{ C } & Mean & $391.4^{x}$ & $32.0^{a}$ & $379.3^{x, a}$ & $31.0^{a}$ & $261.3^{x, a}$ & $21.4^{x}$ \\
\hline & SD & 32.9 & 1.2 & 37.8 & 1.7 & 30.7 & 1.5 \\
\hline & Index & 100.0 & 100.0 & 100.0 & 100.0 & 100.0 & 100.0 \\
\hline \multirow[t]{3}{*}{$1^{\text {st }}$} & Mean & $472.4^{y, a}$ & $30.6^{x, b}$ & $452.8^{y, c}$ & $29.4^{b}$ & $396.6^{y}$ & $25.7^{y}$ \\
\hline & $\mathrm{Sd}$ & 46.7 & 2.1 & 40.5 & 1.7 & 51.9 & 2.6 \\
\hline & Index & 120.7 & 95.6 & 119.4 & 94.6 & 151.8 & 120.3 \\
\hline \multirow[t]{3}{*}{$2^{\text {nd }}$} & Mean & $439.6^{q, b}$ & $32.9^{y, c}$ & $414.6^{b, d}$ & $31.1^{\mathrm{a}}$ & $285.3^{y}$ & $21.3^{y}$ \\
\hline & SD & 25.8 & 1.0 & 33.2 & 1.6 & 44.2 & 2.7 \\
\hline & Index & 112.3 & 102.8 & 109.3 & 100.1 & 109.2 & 99.9 \\
\hline \multirow[t]{3}{*}{$3^{\text {rd }}$} & Mean & $440.9^{z, b}$ & $31.4^{d}$ & $433.9^{y}$ & $30.9^{a}$ & $307.8^{y, b}$ & $21.9^{y}$ \\
\hline & SD & 41.1 & 1.8 & 29.6 & 1.0 & 30.0 & 1.4 \\
\hline & Index & 112.6 & 98.0 & 114.4 & 99.7 & 117.8 & 102.6 \\
\hline
\end{tabular}

Table 5.

Yield and share of wings, neck and abdominal fat $(n=32)$

\begin{tabular}{|c|c|c|c|c|c|c|c|}
\hline \multirow{2}{*}{ Group } & & \multicolumn{2}{|c|}{ Wings } & \multicolumn{2}{|c|}{ Neck } & \multicolumn{2}{|c|}{ Abdominal fat } \\
\hline & & g & $\%$ & g & $\%$ & g & $\%$ \\
\hline \multirow[t]{3}{*}{$\mathrm{C}$} & Mean & $122.5^{x}$ & $10.0^{a}$ & $42.2^{x}$ & 3.5 & $9.5^{x}$ & 0.8 \\
\hline & SD & 16.5 & 0.9 & 4.7 & 0.2 & 7.2 & 0.6 \\
\hline & Index & 100.0 & 100.0 & 100.0 & 100.0 & 100.0 & 100.0 \\
\hline \multirow[t]{3}{*}{$1^{\mathrm{st}}$} & Mean & $141.4^{y}$ & $9.1^{b}$ & $56.7^{y, a}$ & 3.7 & $6.6^{y}$ & 0.4 \\
\hline & SD & 12.9 & 0,6 & 6.2 & 0,3 & 5.2 & 0.3 \\
\hline & Index & 115.4 & 9.2 & 134.4 & 106.4 & 69.6 & 56.0 \\
\hline \multirow[t]{3}{*}{$2^{\text {nd }}$} & Mean & $129.9^{x}$ & 9,7 & $47.2^{b}$ & 3.5 & $5.6^{y}$ & 0.4 \\
\hline & SD & 17.8 & 1.1 & 8.2 & 0.5 & 7.0 & 0.5 \\
\hline & Index & 106.0 & 97.1 & 111.8 & 102.3 & 59.0 & 54.7 \\
\hline \multirow[t]{3}{*}{$3^{\text {rd }}$} & Mean & $141.0^{y}$ & $10.1^{\mathrm{a}}$ & $50.5^{y, b}$ & 3.6 & $6.1^{y}$ & 0.4 \\
\hline & SD & 8.6 & 0.2 & 4.5 & 0.2 & 4.6 & 0.3 \\
\hline & Index & 115.2 & 100.5 & 119.7 & 104.1 & 64.3 & 56.0 \\
\hline
\end{tabular}

$x, y, q, z$ Means within the same column with different superscript letters are different $(P \leq 0.01)$

$a, b, c, d$ Means within the same column with different superscript letters are different $(P \leq 0.05)$

Carcass yield was similar in all groups without significant differences $(P \geq 0.01)$. Broilers from the $1^{\text {st }}$ and $3^{\text {rd }}$ group with added "Min-a-zel" $0.5 \%$ and "Min-a-zel Plus" $0.3 \%$ had carcass yield $72.10 \%$ and $72.20 \%$, respectively, while broilers from the other two groups had $71.87 \%(\mathrm{C})$ and $71.93 \%\left(2^{\text {nd }}\right.$ group $)$.
The results yield and share of main parts of broiler carcasses are presented in Tables 4 and 5 . Masses of breast and drumstick shown the highest level of statistical differences. The highest breast weight had broilers from the $1^{\text {st }}$ group $(472.4 \mathrm{~g})$ which was significantly higher $(P$ $\leq 0.01$ ) than $391.4 \mathrm{~g}$ that was recorded in 
the control group, $439.6 \mathrm{~g}$ measured in the $2^{\text {nd }}$ group and $440.9 \mathrm{~g}$ in the $3^{\text {rd }}$ group. While the weight of breast from broilers in the $2^{\text {nd }}$ and $3^{\text {rd }}$ group were similar $(P \geq$ $0.05)$, they were significantly higher $(P \leq$ 0.01 ) than the breast weight in the control group. Breast share in carcasses was in the range of $30.6-32.9 \%$ in all groups.

Similar results were obtained for drumstick weight. "Min-a-zel" and "Min-a-zel Plus" added in larger amounts showed positive effect on yield of these parts. The highest weight of drumsticks was recorded in broilers of the $1^{\text {st }}$ group (452.8 g) which was no significantly different $(P \geq 0.05)$ than drumstick weight of broilers in the $3^{\text {rd }}$ group $(433.9 \mathrm{~g})$, but both values were significantly higher $(P \leq 0.01)$ than drumsticks weight of broilers in the control group $(379.3 \mathrm{~g})$. Drumsticks weight of $414.6 \mathrm{~g}$ in broilers of the $2^{\text {nd }}$ group was significantly lower $(P \leq 0.05)$ than the drumsticks weight in broilers of the $1^{\text {st }}$ group $(P \leq 0.05)$. Share of drumsticks was similar to breast share and was in the range of $29.4 \%$ in the $1^{\text {st }}$ group to $31.1 \%$ in the $2^{\text {nd }}$ group.

Back weight was similar in the $2^{\text {nd }}$ and $3^{\text {rd }}$ experimental groups (285.3 $\mathrm{g}$ and $307.8 \mathrm{~g}$, respectively). Share was similar too, $21.3 \%$ and $21.9 \%$, respectively. The back weight of $261.3 \mathrm{~g}$ was recorded in the control group of broilers (21.4\%), and was significantly different $(P \leq 0.01)$ from 396.6 $g(25.7 \%)$ in broilers of the $1^{\text {st }}$ group.

Weights of wings were very different. They were similar in the $1^{\text {st }}$ and $3^{\text {rd }}$ group, 141.4 $\mathrm{g}(9.2 \%)$ and $141.0 \mathrm{~g}(10.0 \%)$, respectively. Lower values were recorded in the control group, $122.5 \mathrm{~g}(10.0 \%)$ and in the $2^{\text {nd }}$ group, $129.9 \mathrm{~g}(9.7 \%)$ respectively, which was significantly different $(P \leq 0.01)$ from the values in the $1^{\text {st }}$ and $3^{\text {rd }}$ group.

Neck weight in the control group was 42.2 $\mathrm{g}$, in the $1^{\text {st }}$ group $56.7 \mathrm{~g}$, in the $2^{\text {nd }}$ group $47.2 \mathrm{~g}$ and in the $3^{\text {rd }}$ group $50.5 \mathrm{~g}$. Share of neck was very similar in all groups and was in the range of $3.4-3.7 \%$. The highest weight of abdominal fat of $9.5 \mathrm{~g}$ had broilers in the control group, which was significantly higher than the values in the other groups, i.e. $6.6 \mathrm{~g}, 5.6 \mathrm{~g}$ and $6.1 \mathrm{~g}$ in the $1^{\text {st }}, 2^{\text {nd }}$ and $3^{\text {rd }}$ group, respectively.
Share of abdominal fat was $0.4 \%$ in the $1^{\text {st }}, 2^{\text {nd }}$ and $3^{\text {rd }}$ group and $0.8 \%$ in the control group.

Obtained results showed that mineral adsorbents can be successfully used as additive in the diet for broilers for improved production, better fattening performances and meat safety and quality (Barbut et al., 2005). Although it was not the object of this investigation, it is interesting to mention that fattening of broilers with added mineral adsorbents in the feed mixtures was economically justified (Tica et al., 2010).

\section{CONCLUSION}

On the basis of obtained results, the following can be concluded:

- Feed consumption was the highest in broilers of the control group. The lowest average feed consumption had broilers in the $1^{\text {st }}$ group that was fed diet with added "Min-a-zel" in the amount of $0.5 \%$;

- Feed conversion ratio was the best in the $1^{\text {st }}$ group and the highest in the control group;

- Broilers fed diet with added „Min-a-zel“ in amount of $0.5 \%$ and "Min-a-zel Plus" in the amount of $0.3 \%$ achieved higher final body weights, which were significantly different from other two groups;

- Production number was the highest in the $1^{\text {st }}$ group and the lowest in the control group;

- Broilers fed diet with added "Min-a-zel“ in the amount of $0.5 \%$ and "Min-a-zel Plus" in the amount of $0.3 \%$ had higher weight of breast and drumsticks that was significantly different from other two groups;

- Broilers fed diet with added "Min-a-zel“ $(0.5 \%)$ and "Min-a-zel Plus" (0.3\%) had significantly higher $(P \leq 0.01)$ weights of breast and drumsticks than the broilers fed diet without mineral adsorbents.

\section{ACKNOWLEDGEMENT}

The research has been conducted as a part of the project III46012 ("The research of modern biotechnological methods in feed production in order to increase com- 
petitiveness, food quality and safety") financed by the Ministry of Education, Science and Technological Development of Republic of Serbia.

\section{REFERENCES}

1. Adamović, M., Tomašević-Čanović, M., Milošević, S., Daković, A., Lemić, J. (2003). The Contribution of mineral adsorbents in the improvement of animal performance, health and quality of animal products. Biotechnology in Animal Husbandry, 19 (5-6), 383-395 (in Serbian).

2. Andersen, H.J., Oksbjerg, N., Young, J.F., Therkildsen, M. (2005). Feeding and meat quality - a future approach. Meat Science, 70, 543-554.

3. Andrássy-Baka, G., Romvári, R., Milsits, G., Sütö, Z., Szabó, A., Locsmandi, L., Horn, P. (2003). Non-invasive body composition measurement of broiler chickens between 4-18 week of age by computer tomography. Archiv Tierzucht, 46, 6, 585-595

4. Association of Official Analytical Chemists (A.O.A.C.) (1995). Official Methods of Analysis $16^{\text {th }}$ Edition Vol I. Ch. 4.

5. Barbut, S., Zhang, L., Marcone, M. (2005). Effects of pale Normal and Dark Chickens Poultry Breast Meat on Microstructure Extracable Proteins and Cooking of Marinated Fillets. Poultry Science, 84, 797-802.

6. Bašić, Z., Kilibarda, V., Resanović, R., Maksimović, M. (2009). Investigation of zeolites influence on vitamin B6 content in broilers' chicken meat-method validation. Meat Technology, 50, 3-4, 201-204 (in Serbian).

7. Blagojević, M., Pavlovski, Z., Škrbić, Z., Lukić, M., Milošević, N., Perić, L. (2009). The effect of genotype of broiler chickens on carcass quality in extensive rearing system. Acta veterinaria, vol. 59, no. 1, pp. 91-97.

8. Bočarov-Stančić, A., Nešić, S., Stoičević, L., Nikolić, P., Adamović, M., Grubić, G. (2001). The use of non-nutritive absorptive matters to prevent and eliminate mycotoxin effects. Contemporary agriculture, 50 (3-4), 165-170 (in Serbian).

9. Bogosavljević-Bošković, S., Đoković, R,, Radović, V., Petrović, M., Dosković, V. (2009). The effect of age and rearing system on the proportion of certain meat categories in processed broiler carcasses. Contemporary agriculture, vol. 58, no. 3-4, pp. 100-105.

10. Cmiljanić, R., Pavlovski, Z., Trenkovski, S., Lukić, M. (2005). New trends in poultry nutrition. Biotechnology in Animal Husbandry, 21(5-6) 241-245 (in Serbian).

11. Elaroussi, M.A., Mohamed, F.R., Elgendy, M.S., Abdou, A.M., Hatab, M.H. (2008). Ochratoxicosis in broilers chickens: functional and histological changes in target organs. Inter- national Journal of Poultry science, 7, 5,414422.

12. Karović, D., Đermanović, V., Mitrović, S., Radović, V., Okanović, Đ., Filipović, S., Djekić, V. (2013). The effect of mineral adsorbents in poultry production. Worlds Poultry Science Journal, 69 (2), 335-342.

13. Lilić, S., Vranić, D., Matekalo-Sverak, V., Ilić, T., Ivanović, S., Milićević, D., Dimitrijević, S. (2010). Functional properties of broilers' meat depending on infection with Eimeria tenella. Meat Technology, 51, 1, 1-11 (in Serbian).

14. Mendes, M., Dinçer, E., Arslan, E. (2007). Profile Analysis and growth curve for body mass index of broiler chickens reared under different feed restrictions in early age. Archiv Tierzucht, 50, 4, 403-411.

15. Miazzo, R., Peralta, F., Mangoli, C., Salvano, M., Ferrero, S., Chiacchiera, S.M., Rosa, C.A., Dalcero, A. (2005). Sodium bentonite from south Argentina on the bioavailability of aflatoxin and fumonisina in broilers chickens. Poultry Science, 84, 1-8.

16. Nešić, K., Sinovec, S., Jakić-Dimić, D., Sinovec, Z. (2004). Efficacy of different adsorbents in alleviating zearalenone effects. 18th Cong. IPVS, Proc. vol 2, 733.

17. Okanović, 'Dj., Džinić, N., Filipović, S., Tasić, T., Karović, D., V., Radović, V., Ikonić, P. (2013). The effects of mineral adsorbents added to broilers diet on breast meat quality. Acta Periodica Technologica, vol 44, 95-102

18. Radović, V., Rajić, I., Stanić, D., Nadaždin, M. (2003). The effect of different phosphorus sources on body weight and weight gain in fattening chickens. Biotechnology in Animal Husbandry, 19 (3-4), 43-47 (in Serbian).

19. Radović, V., Karović, D., Okanović, Đ., Filipović, S., Kormanjoš, S. (2009). The effect of mineral adsorbents added into diet, on some results of broilers feeding. Meat Technology, 50, 5-6, 271-275 (in Serbian).

20. Resanović, R.M., Nešić, K.D., Nešić, V.D., Palić, T.D., Jačević, V.M. (2009). Mycotoxins in poultry production. Matica srpska Proceedings for Natural Sciences, 116, 7-14.

21. Ristić, M., Damme, K., Freudenreich, P. (2005). Einfluss phytogener Futterzusatzstoffe auf die Qualität von Geflügelfleisch. Meat Technology, 46, 1-2, 51-55.

22. Serbian Regulations (2010). Regulation for feed quality. Official Gazette, No. 4.

23. Shahin, K.A., Elazeem, F.A. (2005). Effects of breed, sex and diet and their interactions on carcass composition and tissue weight distribution of broiler chickens. Archiv Tierzucht, 48, 6, 612-626.

24. Straková, E., Suchý, P., Vitula, F., Vecerek, V. (2006). Differences in the amino acid composition of muscles from pheasant and broiler chickens. Archiv Tierzucht, 49, 5, 508-514.

25. STATISTICA (Data Analysis Software System), v.8.0. (2008) StatSoft, Inc, Tulsa, OK, USA (http://www.statsoft.com). 
26. Stevanović, J., Palić, D., Okanović, Đ. (2011). Legislation and risks of use of nutritional feed supplements. Food and Feed Research, 38, 1, 21-26.

27. Tica, N., Okanović, Đ., Zekić, V., Filipović, S. (2009). The efect of extruded corn on the economic results of broilers production. Food Processngs, Quality and Safety, 36, 3-4, 59-64.

28. Tica, N., Zekić, V., Okanović, Dj., Karović, D., Milić, D. (2010). Influence of the use of food with addition of mineral adsorbents on economic results in chicken fattening. Econo- mics of Agricultural, vol. 57, specc. n. 2, 337343.

29. Tokić, V., Lazarević, M., Sinovec, Z., Tokić, A. (2007). The influence of different feed additives to performances and immune response in broiler chicken. Acta veterinaria, 57 (2-3), pp. 217-229.

30. Tomašević-Čanović, M., Daković, A., Rotinghaus, G., Matijašević, S., Đuričić, M. (2003). Surfactant modified zeolites: New efficient adsorbents for mycotoxins. Microporous and mesoporous materials, 61, 173-180.

\title{
МИНЕРАЛНИ АДСОРБЕНТИ У ИСХРАНИ БРОЈЛЕРА - УТИЦАЈ НА ПРИНОС И КВАЛИТЕТ МЕСА
}

\author{
Ђорђе Г. Окановић ${ }^{1}$, Дејан Р. Каровић ${ }^{2}$, Вера А. Радовић ${ }^{2}$, Слободан В. Лилић ${ }^{3}$, Славко С. \\ Филиповић ${ }^{1}$ \\ ${ }^{1}$ Универзитет у Новом Саду, Научни институт за прехрамбене технологије, Булевар цара \\ Лазара 1, 21000 Нови Сад, Србија \\ ${ }^{2}$ Универзитет у Крагујевцу, Агрономски факултет, Цара Душана 34, 32000 Чачак, Србија \\ ${ }^{3}$ Институт за хигијену и технологију меса, Каћанског 13, 11000 Београд, Србија
}

Сажетак: У овом раду су приказани резултати истраживања примене минералних адсорбената у исхрани бројлера. Испитано је 400 бројлера Cobb 500 провенијенције, који су подељени у 4 групе: контролна група (К) бројлера храњених без додатог минералног адсорбента; 1. група са додатком Мин-а-Зел у износу од 0,5\%; 2. група са додатком Мин-а-Зел Плус у износу од 0,2\%; и 3. група са додатком Мин-а-Зел Плус у износу од 0,3\%. Тов је трајао 42 дана. Бројлери су узгајани у подном систему држања и храњени ad libitum. Праћене су перформансе това: телесна тежина живих бројлера, конзумирање хране, конверзија хране производни индекс и кланичне карактеристике.

Бројлери из 1. групе постигли су највећу живу тежину и потрошили најмање хране, имали су најбољу конверзију хране и најбољи производни индекс. Такође, и кланичне карактеристике бројлера у 1. групи су биле најбоље, а имали су и највеће учешће највреднијих делова - груди и батака. Анализа добијених резултата, показала је да се минерални адсорбенти могу успешно користити као додатак у исхрани у циљу побољшања това и приноса меса бројлера.

Кључне речи: бројлери, тов, минерални адсорбенти, принос 